\title{
Protocol
}

\section{Whole-Mount In Situ Hybridization of RNA Probes to Plant Tissues}

\author{
Jan Traas
}

This protocol was adapted from "How to Study Gene Expression," Chapter 7, in Arabidopsis (eds. Weigel and Glazebrook). Cold Spring Harbor Laboratory Press, Cold Spring Harbor, NY, USA, 2002.

\section{INTRODUCTION}

The labeling of entire plantlets (whole-mount labeling) is very easy, but it can cause substantial artifacts. Because whole plants are labeled, certain tissues are not readily accessible to the probes, whereas others can often stain nonspecifically. In the hands of the author, for instance, the elongation zone of the root is labeled even in negative controls, whereas mature parts of the roots and hypocotyl tend to be more resistant to probe penetration. Whole-mount labeling should therefore only be used to monitor gene expression in a limited number of organs and tissues - in particular, root meristems, embryos, and very young primordia-and the results should be interpreted with care. A protocol for whole-mount labeling is described here. Positive (e.g., constitutive probe) and negative controls should be included systematically.

\section{RELATED INFORMATION}

This protocol was adapted from Ludevid et al. (1992). Successful in situ localization of RNA and protein has been described for whole mounts of snapdragon floral meristems (Zachgo et al. 2000).

See CSH Protocols article Preparation and Hydrolysis of Digoxygenin-Labeled Probes for In Situ Hybridization of Plant Tissues (this issue) for probe preparation.

\section{MATERIALS}

CAUTIONS AND RECIPES: Please see Appendices for appropriate handling of materials marked with $\langle$ ! $>$, and recipes for reagents marked with $<R>$.

\section{Reagents}

Acetone powder prepared from plant tissue (optional; see Step 18)

Antibody (anti-DIG, alkaline phosphatase-conjugated)

Blocking reagent (e.g. in DIG Nucleic Acid Detection kit [Roche Applied Science]) (optional; see

Step 18)

5-bromo-4-chloro-3-indolyl-phosphate 4-toluidine (BCIP) $(50 \mathrm{mg} / \mathrm{mL})$

$<\mathbf{R}>$ Detection buffer

$<$ !>Dimethyl sulfoxide (DMSO) (optional; see Step 1)

Ethanol (series of 30\%,60\%, 70\%, 85\%, 95\%, 100\%) (Steps 2 and 23 )

$<\mathrm{R}><$ ! $>$ Formaldehyde $(4 \%, \mathrm{v} / \mathrm{v}$ in PBS)

$<$ ! $>$ Prepare fresh from paraformaldehyde.

$<$ ! $>$ Histoclear 


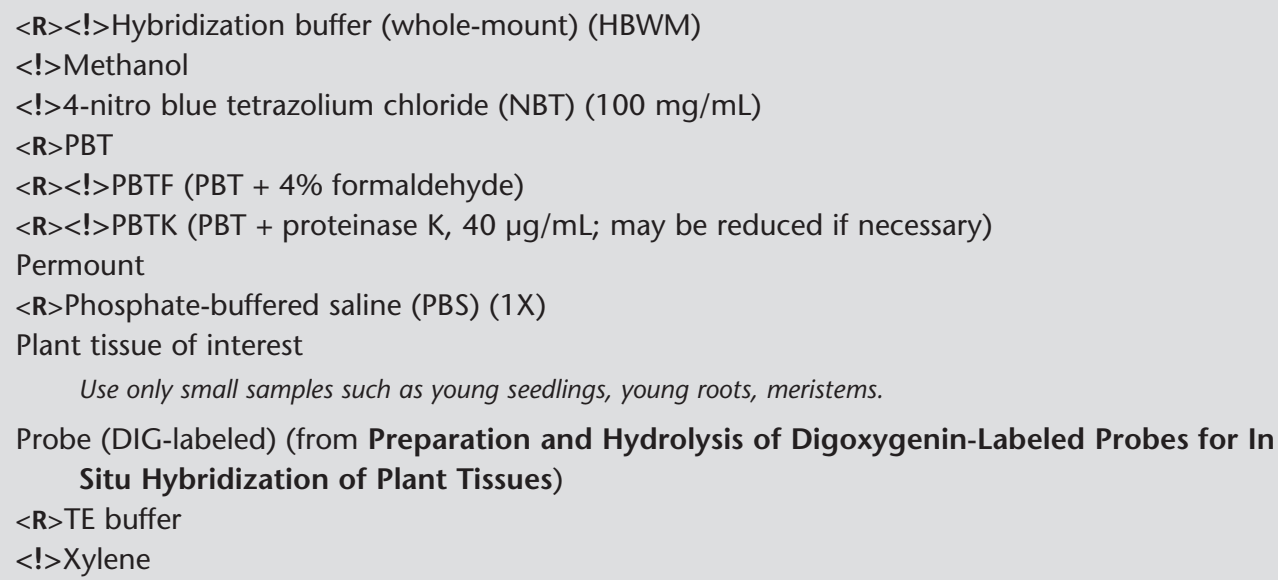

Equipment

Heating block preset to $80^{\circ} \mathrm{C}$

Ice

Microscope (dissecting)

Pipettes (Pasteur)

Tubes (microcentrifuge)

Vials (scintillation)

Water bath preset to $55^{\circ} \mathrm{C}$

\section{METHOD}

\section{Fixation and Dehydration}

1. Fix plant tissue in a scintillation vial using $4 \%(\mathrm{v} / \mathrm{v})$ formaldehyde in PBS as follows:

i. Fix the tissue for $30 \mathrm{~min}$ at room temperature; if necessary, place under vacuum for $15 \mathrm{~min}$.

ii. Leave the tissue in fixative overnight at $4^{\circ} \mathrm{C}$.

Adding 10\% DMSO to the fixative can sometimes improve the results.

2. Dehydrate the samples through an ethanol series: $30 \%, 60 \%, 70 \%, 85 \%, 95 \%, 100 \%, 100 \%$, for 30 min each.

3. Leave the samples in $100 \%$ ethanol for $2-4 \mathrm{~d}$ at $-20^{\circ} \mathrm{C}$.

This helps to reduce background staining, but it does make the samples brittle.

4. Transfer a small number of samples of tissue to a microcentrifuge tube (e.g., up to four 5-d-old plantlets per tube).

\section{Pretreatment}

5. Wash the samples twice with $100 \%$ ethanol.

If necessary, use a drawn-out Pasteur pipette to remove the ethanol. Be careful; the samples are fragile.

6. Wash the samples in xylene for $30 \mathrm{~min}$.

7. Wash the samples four times in $100 \%$ ethanol, followed by twice in methanol.

8. Prepare $50 \%(\mathrm{v} / \mathrm{v})$ methanol/50\% (v/v) PBTF and transfer the tissue to this solution. Incubate for 5 min.

9. Post-fix the tissue in PBTF for 25 min and wash five times in PBT for 10 min per wash. 
10. Incubate the samples in PBTK for 10 min and wash four times in PBT for 5 min per wash.

11. Post-fix the tissue in PBTF for 25 min and wash four times in PBT for 5 min per wash. Leave the tissue in PBT for 60 min. Add an equal volume of HBWM to the last wash.

12. Rinse the tissue twice in HBWM.

\section{Hybridization and Wash}

13. Prehybridize in $\mathrm{HBWM}$ for $3 \mathrm{~h}$ at $55^{\circ} \mathrm{C}$ in a water bath.

14. Denature the DIG-labeled probe for $2-5 \mathrm{~min}$ at $80^{\circ} \mathrm{C}$, and place on ice.

15. Replace the buffer used for prehybridization with fresh prewarmed HBWM. Add the denatured DIG-labeled probe in 1-5 $\mu \mathrm{L}$.

16. Hybridize for $18 \mathrm{~h}$ (i.e., overnight) at $55^{\circ} \mathrm{C}$.

17. Wash the samples as follows:

i. Wash six times in HBWM for 30 min per wash.

ii. Prepare 75\% (v/v) HBWM/25\% (v/v) PBT. Wash for 20 min in this solution.

iii. Prepare 50\% (v/v) HBWM/50\% (v/v) PBT. Wash for 20 min in this solution.

iv. Prepare 25\% (v/v) HBWM/75\% (v/v) PBT. Wash for $20 \mathrm{~min}$ in this solution.

v. Wash four times in PBT for 5 min per wash.

18. Replace the PBT with $500 \mu \mathrm{L}$ of PBT + antibody (diluted 1:2000).

If necessary, blocking reagent can be added according to the manufacturer's instruction. The antibody may also be preadsorbed with an acetone powder made from plant tissue. Incubate overnight in the cold.

19. Wash the tissue in PBT for at least $3 \mathrm{~h}$, changing the PBT several times.

20. Equilibrate the tissue for $5 \mathrm{~min}$ in detection buffer.

21. Add $150 \mu \mathrm{L}$ of NBT $(100 \mathrm{mg} / \mathrm{mL})$ and $150 \mu \mathrm{L}$ of BCIP $(50 \mathrm{mg} / \mathrm{mL})$ per $100 \mathrm{~mL}$ of detection buffer. Incubate the tissue in the NBT/BCIP solution in the dark. Check under a dissecting microscope after $12 \mathrm{~h}$. Incubate for a total of up to $36 \mathrm{~h}$ (or longer).

22. Stop the enzyme reaction in TE buffer.

23. Dehydrate the tissue through an ethanol series (90 sec each), followed by Histoclear, twice for $90 \mathrm{sec}$.

24. Mount with Permount.

\section{REFERENCES}

Ludevid, D., Höfte, H., Himelblau, E., and Chrispeels, M.J. 1992. The expression pattern of the tonoplast intrinsic protein $\gamma$-TIP in Arabidopsis thaliana is correlated with cell enlargement. Plant Physiol. 100: 1633-1639.
Zachgo, S., Perbal, M.C., Saedler, H., and Schwarz-Sommer, Z. 2000. In situ analysis of RNA and protein expression in whole mounts facilitates detection of floral gene expression dynamics. Plant 1 . 23: $697-702$. 


\title{
Whole-Mount In Situ Hybridization of RNA Probes to Plant Tissues
}

\author{
Jan Traas
}

Cold Spring Harb Protoc; doi: 10.1101/pdb.prot4944

\begin{tabular}{cc}
\hline $\begin{array}{c}\text { Email Alerting } \\
\text { Service }\end{array}$ & Receive free email alerts when new articles cite this article - click here. \\
\hline $\begin{array}{c}\text { Subject } \\
\text { Categories }\end{array}$ & Browse articles on similar topics from Cold Spring Harbor Protocols. \\
& Analysis of Gene Expression (197 articles) \\
& Analysis of Gene Expression in Plants (19 articles) \\
& Analysis of Gene Expression, general (129 articles) \\
& Arabidopsis (71 articles) \\
& Cell Biology, general (1382 articles) \\
& In Situ Hybridization (93 articles) \\
& Laboratory Organisms, general (923 articles) \\
& Molecular Biology, general (1293 articles) \\
& mRNA (132 articles) \\
& Non-isotopically Labeled Probes (40 articles) \\
Plant (105 articles) & Plant Biology, general (118 articles) \\
& Probes (92 articles) \\
& Probes, general (72 articles) \\
RNA (317 articles) \\
RNA, general (269 articles) \\
Visualization (524 articles) \\
Visualization of Gene Expression (127 articles) \\
Visualization, general (369 articles) \\
\end{tabular}

